Article

\title{
Reading (with) Hannah Arendt: Aesthetic Representation for an Ethics of Alterity
}

\author{
Andreea Deciu Ritivoi
}

Department of English, Carnegie Mellon University, Pittsburgh, PA 15228, USA; aritivoi@andrew.cmu.edu

Received: 28 May 2019; Accepted: 12 September 2019; Published: 24 September 2019

\begin{abstract}
Hannah Arendt's interest in literature was part of a broader concern, which was inspired by her reading of Kant, with the role played by aesthetic representation in ethical and political judgment. Her rich repertoire of writings about literature deserves to be considered alongside the works more commonly associated with the ethical turn in literary studies. Arendt's unique contribution, I argue here, is a heightened awareness of the assimilative tendencies of aesthetic and cultural representation, coupled with a critique of empathy as potentially illusory or even condescending when confronted with a political judgment that is set up to absorb difference. To recognize alterity requires us, if we follow Arendt, to understand otherness "in acting and speaking," as she argued in The Human Condition. Much of her philosophical and political work was dedicated to understanding the obstacles facing human togetherness, so that she could suggest ways for us to overcome them. Aesthetic representation, in her view, was one of the most effective strategies for achieving community because it offers a reconstruction of another's viewpoints that invites both an imaginative projection and a sustained cognitive effort.
\end{abstract}

Keywords: alterity; compassion; enlarged thinking; human rights; judgment; refugees; sensus communis

\section{Introduction: Hannah Arendt and the Ethical Turn}

"If we want to know what absolute goodness would signify for the course of human affairs ... we had better turn to the poets," advised (Hannah Arendt [1963] 2003, p. 262). The answer she found in literature was perhaps unexpected: absolute goodness, she learned from Herman Melville, is not preferable to absolute evil-at least in political affairs. More interested in the political value of ethical relativism than moral absolutes, Arendt grounded ethics in aesthetics because she viewed aesthetic representation as a way of understanding how the world appears to different human beings. To let the imagination "go visiting" another's world, as she put it, was all the more important when it could recover marginalized or repressed perspectives. Arendt shared with Bertolt Brecht a "passionate longing for a world in which all can be seen and heard, the passionate wrath against a history that remembered a few and forgot so many" (Arendt [1948] 2007a, p. 141). In that regard, her work anticipated strikingly the ethical turn we commonly place in the 1980s (Harpham 1995; Eskin 2004; Davis and Womack 2001). Normally situated under the auspices of Emmanuel Levinas's and Jacques Derrida's philosophical work, the ethical turn brought along an orientation toward alterity that had not only a moral aim but an emancipatory political mission as well. In the aftermath of the ethical turn, we have become accustomed to assuming that through "detailed descriptions," literary representation can nurture our "imaginative ability to see strange people as fellow sufferers" (Rorty 1989), instill compassionate responses to "acts of injury (Scarry 2014), and be "a valuable source of deliberative enrichment", which would make us into better citizens (Nussbaum 1992). The ethical turn has drawn attention to the "experience of otherness," and has led to "a certain ethics: a self-dispossession in favor of the text, another voice in the room" (Brooks 2014). 
Arendt belonged to the Central European Jewry for whom the experience of otherness was connected to the erasure of difference-both as a violent act of destruction and, in the form of assimilation, a strategy of survival. Embedded in, and justified by the ideal of Bildung, ${ }^{1}$ assimilation promised to erase or at least disguise origin, and make one a member of the good society: "Every Jewish youth who was able to rhyme passably played the young Goethe, as everyone able to draw a line was a future Rembrandt, and every musical child was a demonic Beethoven. The more cultured the parental homes, the more coddled were these imitative Wunderkinder" (Arendt [1943] 2007, p. 63). Imitation erases otherness. Yet despite her condemnatory tone, Arendt recognized that the pull of aesthetic and cultural models was part of a humanism committed to the ideals of universalism. These ideals, she argued, had emerged along Roman and Greek lineages into a vision of cultura animi, which defined aesthetic cultivation as appreciation for what matters and endures in the form of a painting, a cathedral, a symphony, or a poem (Arendt 1961).

The ideal universalism of cultura animi can disguise a colonization of difference, whereby we see others as resembling us and thus reduce them to a humanity defined by our criteria. If the essence of ethical behavior is to acknowledge otherness, as Levinas urged us, our first task is to protect it against assimilative, or "subsumptive" practices (Meretoja 2017) that reduce the other to the expectations or demands of the self. We encounter alterity as an appearance in a multitude of appearances, seeking, inviting, and fearing disclosure. To recognize and respect alterity requires us to understand another's standpoint and see how it came about, as well as what beliefs and values it makes possible. Finding the "viewpoint from which to look upon, to watch, to form judgments, ... to reflect upon human affairs" (Arendt 1989, pp. 43-44) is at the core of an ethics of alterity that demands that we neither presume to know another's standpoint by positing similarities to our own, nor seek to approach it from an abstract view from nowhere.

Arendt's ethics of alterity was inspired by her reading of Immanuel Kant's political philosophy, in his Critique of Judgment, and revolved around his concept of enlarged thinking, as an understanding that is informed by looking at the world from a variety of standpoints. However, she was skeptical of the virtues of empathy and compassion in creating an enlarged thinking, which, she insisted, "does not consist in an enormously enlarged empathy through which one can know what actually goes on in the minds of all others" (Arendt 1989, p. 43). She was equally skeptical of compassion, the "most devastating passion" (Arendt [1948] 2007a, p. 254), in guiding an enlarged thinking into political judgment, and the French Revolution was her cautionary tale. ${ }^{2}$ Hungry men acting on behalf of the hungry masses everywhere, the Revolutionaries relied on compassion to open "the heart of the sufferer to the suffering of others, whereby it established and confirmed the 'natural' bond between men which only the rich had lost" (Arendt [1963] 2003, p. 261). Such a natural bond, to Arendt, is either an illusion or a fleeting experience. Responding with compassion to another's suffering does not require judgment. The hungry men and women of the French Revolution did not have to convince one another of the shortcomings of a corrupt aristocratic regime. They felt each other's pain because each of them experienced it individually. Their compassion was not an enlarged thinking because it did not require an imaginative reconstruction of another's standpoint.

For Arendt, aesthetic representation is not only a way of entering another's standpoint, but also an escape from "the demands of oikos" (Lupton 2014, p. 289) and the everyday world of "pragmata" and into "political time" (Gottlieb 2007, p. xiii). Her rich repertoire of writings about literature

1 Such an assimilation is different from religious conversion, but their result is similar as both require an erasure and radical reconstruction of identity.

2 To the failure, in her reading, of the French Revolution, Arendt counter-posed the success of the Founding Fathers. Arendt's representation of the American Revolution might be an idealized one, as she's been reproached, a byproduct of her faith in a political rationality formed around argument, or even of her optimism as a European refugee finding freedom in America (Nisbett 1977; Barber 2010). Her admiration for the Founding Fathers, against her reservations toward the French Revolutionaries, stems not only from her privileging of the civic over the ethnic, but also from her particular understanding of politics and the role of argument in a political context. 
deserves to be considered alongside the works more commonly associated with the ethical turn. Arendt's unique contribution, I argue here, is a heightened awareness of the assimilative tendencies of aesthetic and cultural representation, coupled with a critique of empathy as potentially illusory or even condescending when confronted with a political judgment that is set up to absorb difference. What we first need is to create ethical and political conditions for self-disclosure, and to achieve, in Arendt's terms, "human togetherness," as an ethical framework for being "with others and neither for nor against them" (Arendt [1958] 1998, p. 180). Much of her philosophical and political work was dedicated to understanding the obstacles facing "human togetherness," so that she could suggest ways for us to overcome them.

For the purposes of this essay, I adopt Geoffrey Galt Harpham's definition of ethics as "the arena in which the claims of otherness-the moral law, the human other, cultural norms, the Good-in-itself, etc.- -are articulated and negotiated" (Harpham 1995, p. 394). For Arendt, this arena is fundamentally a political one, emerging out of an ontology of plurality (Sjöholm 2015). Arendt's ethics were connected to her ideal of political community as a space "in which we are judged not through the characteristics which define us at birth, but through our actions and opinions, by what we do and say and think" (Benhabib 2004, p. 59). The reality of a political community, as she experienced it, was drastically different. Whether writing about a Jewish socialite hosting the most prominent salons in 18th century Berlin or about anonymous refugees of World War II, Arendt was consistently preoccupied with questions of belonging and otherness. She herself was a figure of alterity in the political tragedy of the 20th century: arrested by the Gestapo for participating in anti-fascist political activities; interned as an enemy alien at Gurs, France; and, forced to leave Europe and become a political refugee in the United States. Her identity, anchored first and foremost in her Jewishness, was in turn that of a political prisoner, an enemy alien, and a stateless person. She experienced, as millions of other refugees then and now, the anguish of disclosing an alterity through the identity stamp in a passport or entry visa that could be a death sentence. Across several countries and two continents, Arendt followed the path of the quintessential figure of modernity-the refugee.

Giorgio Agamben has urged us to turn the figure of the refugee into a foundational political subjectivity in order to interrogate the distinction between citizens and aliens as the basis of the political order, which renders the former natural and the latter deviant. Prioritizing the refugee as the "truth of humanity" forces us to recognize that our sense of belonging and shared life risks is the result of how we conceal alterity rather than disclose it. ${ }^{3}$ The refugee embodies an alterity tempted, urged, and pushed to assimilate rather than self-disclose, ready to receive recognition. To articulate an ethics of alterity from the perspective of the refugee is to be concerned with the ways in which difference gets erased rather than embraced.

\section{Arendt's Literary Ethics}

Arriving in New York in 1941 as a refugee, Arendt entered the American professional scene first through its literary community—which she significantly impacted. At Schocken Books-where she worked as an editor between 1946 and 1948- she was responsible for the first American edition of Kafka (King 2017). Her friendship with poets Randall Jarrett and W.H. Auden, novelist Mary McCarthy, and literary critic Alfred Kazin, among others, inducted her, even if ex officio, into the world of the literati before she claimed, always reluctantly, membership in the philosophical profession (Arendt [1964] 2000). Unencumbered by any disciplinary commitments to literary study and free

3 Agamben urges us as well to question the assumption of a sovereign people and pushes his critique of the citizen-refugee opposition to the point of questioning the political necessity of the nation-state. Most scholars do not see Arendt going in the same direction, and the nation-state remains the frame of reference for her (Agamben 1995). 
to flaunt any theory in vogue ${ }^{4}$ she could foray the depths of a literary text and make it part of a philosophical reflection instead of using a particular philosophical angle to interpret it.

Arendt's literary ethics was defined by the pained cosmopolitanism of the exile and a bilingual writer's "condensation of ... different facets of personae" (Weigel 2012, p. 77). Alterity was at the core of this ethics. The author of many literary reviews, Arendt played an important part in introducing American audiences to books by German writers who might have otherwise eluded them: Bertolt Brecht, Hermann Broch, Stefan Zweig, and Adalbert Stifter, in addition to Kafka. Her attention to literature, however, went far beyond that of a broker for German culture, and some of her most insightful literary reflections focus on American authors such as Herman Melville and Ralph Waldo Emerson. Whether she wrote about poetry or about fiction, Arendt often found political allegories in these texts. This deciphering impulse reveals her pursuit of literary works with an "ethical substance and truthfulness" (Heller 1977, p. 7), which to her often amounted to capturing the struggles of the individual in an oppressive environment. Arendt not only resonated with the toll such struggles took on individual lives, but pondered them as well for a larger meaning that could provide insight into the general political phenomena underlying them.

This political-cum-moral concern led her to Kant's political philosophy, and along with him, to ask: how can judgment allow us to participate in the public life of a political community, as good citizens, regardless of whether we are morally good as persons (Arendt 1989, p. 17)? In a Kantian sense, to be a good citizen means to be able to process difference and to enlarge one's thinking through "taking the viewpoints of others into account" (Arendt 1989, p. 42). The foundation of public and political morality, for both Kant and Arendt, lies not in adherence to norms but in perspective-taking. Kant defined judgment as the ability to look at the world from another standpoint than my own and to see the difference between representations informed by distinct viewpoints. To access another's standpoint requires an imaginative projection as we can never be in the mind of another. We train our imagination on compelling examples that are singular yet also generalizable. This view is also present in scholarship associated with the ethical turn, which points out that, while "resisting or exceeding all pre-existing general determinations" (Attridge 2004, p. 63), aesthetic representations orient us toward alterity because they have exemplary validity. Arendt's interest in aesthetic representation is also connected to her desire to articulate a conception of political agency that emphasizes an ethical concern for others as well as the ability to formulate judgment about particular situations (Singer 1997). Faced with the unexpectedness of contingency, political agency requires the ability to see general patterns in particular situations, and then to extract new general principles that can be recognized, re-affirmed, or reviewed later on. Ethical and moral judgments are embedded in this form of thinking as well. Consider Arendt's illustration of how we come to understand a virtue such as courage, and emulate it in our own lives-rather than knowing what it means in an abstract manner, we deduce it from exemplary manifestations that become emblematic, and come to life in heroic figures such as Achilles. We never encounter Achilles, but his exemplary courage becomes the kernel that we recognize in manifestations of courage in our everyday life. Whether or not it is Achilles we associate with courage, or another exemplary figure, our moral understanding is grounded in exemplarity.

To view literary representation as exemplary means that we assume it can offer us, as readers, "some truth about [life, and the world, and man]," as Arendt noted about the kind of reader Kafka addressed. (Arendt [1948] 2007b, p. 105). Exemplarity reveals the phenomenon—in the sense Walter Benjamin attributed to the term—or blueprints of reality, in the sense she attributed to Kafka. "The wonder of appearance" that was "always at the center of all (Benjamin's) concerns" (Arendt 1968, p. 12) is resistant to the mode of enunciation. Likewise, "blueprints," she explains, "cannot be understood except by those

4 Arendt's skepticism regarding the value of much of the professional literary criticism produced at the time she was writing comes across clearly in several of her essays, but perhaps is the bluntest in her essay on Kafka. 
who are willing and able to realize by their own imagination the intentions of architects and the future appearances of buildings" (Arendt [1948] 2007b, p. 77).

The metaphor of the blueprint conveys the emergent nature of aesthetic representation, which does not reproduce an observable reality or invents a purely fictional one, but rather captures configurations in which we can discern both a world now around us and the world as it is most likely to take shape. Building his narrative forms on the "abstractness of the general" Kafka created characters we could never "meet in a real world, for they lack all the many superfluous detailed characteristics which together make up a real individual" (Arendt [1948] 2007b, p. 75). For Arendt, the feeling of absurdity we get from reading his stories is a strategy for exposing the arbitrariness of what we come to take for necessity. Arendt's interest in Kafka is connected to his avoidance of "emotional excess," as Judith Butler aptly put it, which makes room for referential restraint and allows exemplarity to emerge "out of factors contributing to typical human failure, and not out of a real event" (Butler 2011, p. 79).

The importance of balancing the generality of representation with the particularity of experience comes through in Arendt's admiration for the linguistic precision of good writing. In Stifter-one of her favorite authors-semantic precision is the mark of a stylist who seeks to project the reader into the palpable reality-or phenomena-of another's world. "He will never write of a rider on a horse," she comments about Stifter, "but rather of a certain well-described man on a dapple gray" (Arendt 2007a, p. 111). Beyond vivid detail, such representation delivers what Benjamin calls "thought-things" (Arendt 1968, p. 48). Thought-things give appearance to life and direct our attention to "the actions, gestures, words, and movements of other people (that) underlie our sensible experience" (Sjöholm 2015, p. 6). To make sense of aesthetic appearance through thought-things requires judgment that resembles a kind of "drilling," which Arendt contrasts with "excavating" or creating explanations that "seek to provide a causal or systematic connection" (Arendt 1968, p. 48). "Drilling" projects us into another's world without rendering it predictable or making it easily recognizable by identifying a comparable experience in our own life. As a metaphor for judgment, "drilling" reminds us, to use Svetlana Boym's terms, that "judging requires a double movement-defamiliarizing experience through the practice of thought and defamiliarizing habits of thought in response to changing experience" (Boym 2012, p. 265).

Benjamin cultivated an aesthetic Arendt describes as "pearl diving," a deliberately fragmented writing relying on collected quotes with minimum commentary or exegesis, in an attempt to recreate the interrupted, discontinuous nature of our perception and understanding. Although influenced by Benjamin, Arendt's aesthetic vision places a stronger emphasis on its capacity for creating structures of intelligibility and a "particularly powerful medium for reflection on the relation between absence and presence, the 'then' and the 'now'" (Gottlieb 2007, p. xiii). Reading William Faulkner's work reinforced for Arendt her conviction "that a political order cannot exist without talk about, and hence remembrance of, past deed and events" (King 2017, p. 117). However, it is in Brecht where she finds poetry wielding "the political power ... to perform the essential democratic function of bringing silenced people and experiences into the public space" (Storey 2015, p. 871). Brecht's "anti-psychological insistence upon the events themselves" (Arendt [1948] 2007a, p. 137) gave him an affective agnosticism in representing the political reality of his time. By not qualifying events, he remained detached from any given viewpoint. To depict the war as awful is to communicate a particular standpoint on the war; by withdrawing from any particular viewpoint, Brecht could capture the manifold of perspectives. ${ }^{5}$ This simultaneously political and aesthetic commitment is consistent, in Arendt's view, with Brecht's selection of genres expressing the political subjectivity of the everyday man or woman: the ballad and the epic theatre. Brecht chose aesthetic genres that could capture common sense, a sensus communis acting both as mode of thinking and as set of beliefs that inform the political judgment shared by the

5 According to Arendt, when Brecht started becoming an explicit supporter of Stalinism, the quality of his poetry deteriorated because he was no longer expressing a poetic truth, but rather telling political lies. "It is entirely to Brecht's credit that he writes badly when he does not see the truth" (Arendt [1948] 2007a, p. 141). 
members of a community. Sensus communis requires a continuous creative reconstruction of others' thinking, if it is to avoid its reduction to preconceived ideas, and it achieves this reconstruction by gathering the members of a community in the act of sharing their judgment over what brings them pleasure and what they regard as beautiful. Jonathan Peter Schwartz explains: "to the extent judging subjects participate in sensus communis-no matter what their cultural backgrounds and practices may be-as they 'quarrel' or debate about objects of taste, they will over time move toward consensus as they cultivate more sensitivity in their common sense structures of judgment" (Schwartz 2015, p. 117).

Arendt's conception of common sense, Andrew Norris has argued, "is an affect, a feeling caused by the harmonious play between our understanding and our imagination. It is a kind of pleasure that, while involving the cognitive faculties, is not itself the result of any cognitive process" (Norris 1996, p. 182). While I disagree that Arendt views in common sense an "affect," which to me would not be consistent with her dismissal of empathy, Norris helps us understand the equal importance of imaginative projection and cognitive effort required for reconstructing another's standpoint and articulating a sensus communis that recognizes distinct standpoints. However, Arendt was preoccupied by the erasure of standpoints that can be rendered incommensurate with the aesthetic and political paradigm of sensus communis. She was interested in community as much as she worried about estrangement-both in the key of a modernist aesthetic and even more so as a political condition. It is no surprise, then, that one of her earliest incursions into literary analysis focused the poignant modernist metaphysics of estrangement as she discovered it in the work of Rainer Maria Rilke.

In an essay co-authored with her then husband Günther Anders, Arendt reads in the Duino Elegies a meditation on the realm of the possible as "estrangement from the world" (Arendt [1930] 2007, p. 6), in which the focus is not solely on what we can imagine but also on how we acquire knowledge of something not yet in existence, hovering at the threshold of reality. Rilke's tropes of loss and absence are listening and hearing. For Arendt, he is the poet of an "acoustic world" in which sound, voices, supplication, and invocation create a "being-in-hearing" (Arendt [1930] 2007, p. 4). Such emphasis on sound, which might be connected to her Jewish background, ${ }^{6}$ reaffirms her concern with alterity. As Dominic Pettman has argued, "the abstract Other ... is registered aurally, and the rest of the universe is assembled from this mobile but steady sonic source, including the listening self" (Pettman 2017, p. 2).

To what extent does an aesthetic grounded in estrangement desire to be understood, and to what extent can it be understood? These were questions Arendt asked in her reading of the Duino Elegies (Arendt [1930] 2007, p. 1). The same questions could be raised about understanding another's subjectivity under conditions of political estrangement such as those directly experienced by Arendt. In response, she analyzed the representational mechanism of such an understanding, and tried to extrapolate from it the conditions for a sensus communis that is cosmopolitan-even in the face of political institutions that seek to erect boundaries and maintain the strict separation between outsiders and insiders. Her conception of sensus communis stretched the "built-in cosmopolitan structures and inclinations" of the original Kantian notion (Schwartz 2015, p. 121) by affirming the value of plurality in assembling an enlarged thinking that can inform our understanding of a particular situation and its moral significance (Benhabib 1988). However, the question remains: how does sensus communis fulfill its cosmopolitan potential and aspirations? To answer this question, we must first understand what stands in the way of cosmopolitan aspirations.

\section{Being Human: Statelessness and "Surplus Subjects"}

“One judges always ... guided by one's community sense, one's sensus communis. But in the last analysis, one is a member of a world community by the sheer fact of being human; this is one's 'cosmopolitan existence.'" (Arendt 1989, p. 76). There seems to be no irony in this summary and interpretation of Kant that Arendt offered to her students at the New School, where she delivered her 
lecture series on the third Critique. Yet, Arendt was one of the harshest critics of cosmopolitanism viewed in conjunction with a discourse of human rights, as it was emerging in the aftermath of World War II. In one of the political essays she published soon after arriving in the United States, "We Refugees," Arendt offers a searing, albeit indirect, critique of the assimilative ethics of cosmopolitanism, read through the lens of the fate of World War II Jewish refugees. Arendt wrote the essay with the awareness that within the nation-space, a person exists not as a human being but as a citizen or an alien. As Giorgio Agamben would put it later, "rights ... are attributable to man only in the degree to which he is the immediately vanishing presupposition (indeed, he must never appear simply as man) of the citizen" (Agamben 1995, p. 117). Seeing either a citizen or an alien in the human being in front of us entails a shift in perspective that is not only political, but also aesthetic insofar as it implicates a mechanism of representation. One of the characters featured in the essay is the sorry figure of a Mr. Cohn, who is "150\% French in France, 150\% American in America," as metaphor of a desperate eagerness to escape the refugee condition, and tragi-comic awareness that the only escape possible is citizenship.

The cold affect of the essay speaks to Arendt's unique rhetorical persona, which I have described elsewhere as detached and impersonal (Ritivoi 2014). This persona, as I view it, emulates impartiality and invites thinking in the place of another, rather than compassion. Impartiality is "not the result of some higher standpoint that would then actually settle the dispute" of different representations "by being altogether above the melee (Arendt 1989, p. 42). The explicit denial of pity functions in the essay the same way as emotional restraint did for Kafka, to reconstruct the experience of refuge in its generality, while Arendt's use of irony works, in Brechtian fashion, as a way of magnifying differences and zooming in on the particular. Arendt offers a first-person standpoint, explicitly self-identifying as a Jewish refugee both deictically (through the pronoun we) and through an objective designation of her own political status at the time. However, at the same time she questions what it means to assert one's identity against political and cultural practices that constrain us. "The chief trap in life," Arendt wrote in her reflections on Isak Dinesen, "is one's own identity" (in Gottlieb 2007, p. 262). This statement has a double meaning: on the one hand, it shows Arendt's skepticism regarding an identity defined along norms and expectations. However, on the other hand, it acknowledges that the disclosure of identity can function as a political entrapment as well. "We don't like to be called 'refugees,'" warns the essay. To be called a refugee is to occupy a political space always haunted by the threat of violence. Arendt signals the dangers of the appellative as semantic dilemmas associated with the politically charged efforts to disclose oneself while immersed in an anguished search for safety:

We ourselves call each other 'newcomers' or 'immigrants.' Our newspapers are papers for 'Americans of German language;' and, as far as I know, there is not and never was any club founded by Hitler-persecuted people whose name indicated that its members were refugees. ... With us the meaning of the term 'refugee' has changed. Now 'refugees' are those of us who have been so unfortunate to arrive in a new country without means and have to be helped by refugee committees. (Arendt [1943] 2008, p. 264)

The standpoint of the refugee is defined by the difficulty of self-disclosure. Listing the refugees' naming devices as strategies of avoiding self-disclosure, Arendt exposes the conflation of assimilation and rejection in a political order predicated on the distinction between aliens from citizens. The freedom that awaits the refugee on the shore of their new country is a "gift (that) inevitably calculates and coheres an ordered taxonomy of what is deemed necessary for a human being" (Nguyen 2012, p. 15). Therefore, as Arendt put it, "if we are saved we feel humiliated, and if we are helped we feel degraded." Help brings along a reification, and thus potential dismissal of otherness. The fact that Arendt reads this dismissal in moral terms as humiliation and degradation points to the necessity she sees in maintaining one's right to self-disclosure. At the same time, as soon as difference is read antagonistically, the impulse to control and subsume it places the autonomy of the other under threat.

Deferring the explicit mention of the word Jew and its cognates until halfway through the essay, Arendt represents a standpoint that does not merely belong to another but is that of an alien. 
Otherness becomes estrangement, as "Arendt's ' $w e^{\prime}$ linguistically enacts its own historical unhoming" (Stonebridge 2011, p. 74) through irony that vacillates between somberness and detachment. "The less we are free to decide who we are or live as we like," Arendt writes, "the more we try to put up a front, to hide the facts, and to play roles.... Our identity is changed so frequently that nobody can find out who we actually are" (Arendt [1943] 2008, p. 270). Such emphasis on asserting an identity might be surprising in a thinker who was primarily interested in literary works with an "anti-identitarian character" (Storey 2015, p. 884), but it reveals Arendt's political concern with how we access the standpoint of another human being. Arendt frequented writers who turned their artistic gaze outwards rather than inwards, scrutinizing the world and trying to make sense of it rather than probing the depths of a mysterious psyche. Her preference for poets such as Brecht, Auden, or Jarrell is part of her larger quest for an expressive language with political heft, language in which to communicate the "least welcome truths" (Arendt quoted in Storey 2015, p. 879). Such is the truth of the fact that, deprived of an identity they can own and disclose, forced to take on a protective disguise, the refugees are left outside a sensus communis and ultimately forced into worldlessness. For them, there is no basis upon which they can connect to others as autonomous, self-disclosing agents.

The refugees' standpoint is not only different from that of the citizen with full rights issued by his membership in a community, but also incommunicable in its utter difference. What the refugees have lost includes, in addition to the freedom of thinking as authentic expression of their selves, the very possibility of communicating their experience.

We lost our home, which means the familiarity of daily life. We lost our occupation, which means the confidence that we are of some use in this world. We lost our language, which means the naturalness of reactions, the simplicity of gestures, the unaffected expression of feelings. We lost our relatives in the Polish ghettos and our best friends have been killed in concentration camps, and that means the rupture of our private lives. (Arendt [1943] 2008, p. 264, my emphasis)

This cumulated loss defies any easy attempt at restoration, but similar to the estrangement evoked by Rilke in the Duino Elegies, it serves as an adumbration of another's standpoint and obligates us ethically to recover it by insisting on how far removed it is from our own experience. For an alterity under siege, self-disclosure is haunted by the futility poetically described in the Duino Elegies as perpetual estrangement. At the same time, as Arendt commented on Rilke, "in contrast to every other historically recorded estrangement from the world, this estrangement is not directly or originally determined as transcendence, nor does it escape into transcendence; it is rather characterized by the detour it takes" (Arendt [1930] 2007, pp. 6-7). For Rilke, this detour was the very act of rescuing estrangement through naming, which becomes a form of "preservation from destruction" (Ibid). Naming the refugee's loss is a way of preserving in effigy what was lost as well as disclosing the attachment.

"We Refugees" was published in the Jewish-American periodical Menorah Journal, but its rhetorical construction suggests that it was addressed to a larger American audience as well; the audience of citizens, rather than immigrants. ${ }^{7}$ The essay serves as a reminder that the assimilative pull of a sensus communis claiming to be cosmopolitan uses the promise of survival to contain difference, and it does so by promoting a political rationality of individualism, which amounts to political anomie. "We Refugees" does not identify any real cases, but it is not hard to recognize Stefan Zweig as one of Arendt's reference points in her mention of the tragic recurrence of suicides among refugees.

7 By Berel Lang's distinction between contingency- and coherence-based models of reasoning undergirding philosophical writing, Arendt's style fits best in the first category. Lang's distinction is useful because it draws attention to the fact that styles of argument are moral modalities as well: how writers choose to formulate ideas and present them to the reader reveals their own ethical assumptions vis-à-vis their audience. In a coherence model, the author remains distanced from the audience and offers arguments that are intended to convince based on their decontextualized, absolute logical force rather than by appealing to a reader's values. In the contingency model, the author and the writer are engaged in a dynamic relationship as equals, focused on shared values through familiar examples (Lang 2010). 
Zweig's suicide represents to her an abdication from the need to survive that constitutes, in the context of the Nazi genocide of the Jews, a political responsibility. Suicide for a refugee was not only cowardly, in her view, but evidence as well that the seeming willingness to start over and acquire a new self in a different political and cultural paradigm of a new country is a form of self-negation.

Born in 1881 in Vienna in a wealthy Jewish family, a friend of Sigmund Freud and Theodor Herzl, interested in Jewish matters but without identifying primarily as a Jew, Zweig became a successful writer at a time when Jewishness could appear secondary to the social standing of a respected intellectual. The utopianism of cosmopolitan spaces such as Vienna was their seeming indifference to ethnic or racial difference. Similar to many other secular or assimilated Jewish intellectuals of his generation, Zweig identified as a citizen of the world. However, this was a world that only respected them for having assimilated through their upbringing and cultural accomplishments-and tolerated them despite the fact that they were Jewish rather than because their Jewishness did not register. After the Anschluss, Zweig fled Austria, first to England, then the United States, and finally Brazil—where he and his wife committed suicide in 1942. In the suicide note he sent to his friend, French writer Jules Romain, Zweig explained his decision as the result of an "inner crisis" caused by his inability to reconcile himself to having become an anonymous exile, estranged from his environment. In her review of Zweig's memoir The World of Yesterday, Arendt interprets his decision to commit suicide consistent with the views she had expressed in her 1943 essay, as based on the fact that he "considered it unbearably humiliating when the hitherto wealthy and respected citizens of Vienna (i.e., of Jewish origin such as himself) had to be begging for visas to countries which only a few weeks before they would have been unable to find on a map" (Arendt [1943] 2007, p. 59). To her-the space where Jewish artists and intellectuals such as Zweig had felt so much at home-that exile seemed unbearable and unfathomable, was phantasmagorical, no more on a map of political realities than Brazil had been on Zweig's map of desirable destinations.

Zweig's and others' illusion of belonging to a polity of artists and intellectuals had led them to perceive their refugee status as "social humiliation," she argued, at a time when political resistance was the only way they might have saved themselves. While to Zweig being a refugee was a disgrace and a personal defeat, Arendt views it as a mark of an alterity from which one can only "escape into a political attitude and a struggle for the honor of an entire people" (Arendt [1943] 2007, p. 68). The "international society of the successful ... in which Jews enjoyed equal rights" (Arendt [1943] 2007, p. 68) was a political fiction disguising the omnipotence of the citizen as metonym of the state. Before being deported to extermination camps, Jews were first denationalized. Reducing them to merely human was the preamble to taking their humanity away. Zweig sought a "world citizenship" that could offer him "the possibility of being recognized by unknown people, of being admired by strangers" (Arendt [1943] 2007, p. 67), but his daily existence never ceased to unfold in the context of a nation-state that fully controlled his rights. Once being a Jew was a disgrace, it did not matter who the individual Jew was. All Jewish people became identical to one another regardless of how social standing grounded in education and cultural attainment might have once differentiated them. Anonymity was only one step behind annihilation. Zweig's "world of yesterday," the cultured international society of cosmopolitan intellectuals who deemed themselves above discrimination, vanished not swept away by a new era of intolerance and hatred but collapsing onto its own inauthenticity. The cosmopolitan sensus communis affirmed by Zweig was the framework of an assimilative ethics that would eventually erase his standpoint. Zweig's tragedy began with his abdication from affirming his alterity.

The refugees' standpoint is defined by the perpetual threat of the nation-state: identified, or rather exposed by their passports, birth certificates, "sometimes even income tax receipts" they can always become victims to "discrimination as the social weapon by which one may kill men without bloodshed" (Arendt [1943] 2008, p. 273). An assimilative ethics faced the refugee with the standpoint of the citizen, and thus revealed the "possibilities of human existence, which are infinite as is creation," while reminding her as well that "the recovering of a new personality is as difficult—and as hopeless—as 
a new creation of the world" (Arendt [1943] 2008, p. 271). Refugees such as Mr. Cohn, who, hard as they might try, can never belong, show that an assimilative ethics creates a subjectivity in excess-150\% French in France, or 150\% American in America-which is at the same time one reduced to "bare life." Assimilation is a costly fantasy, since the nation-state always flags alterity, making the refugee's difference dangerous to disclose. Mr. Cohn's Frenchness (or his Americanness, or his Germanness) is inevitably in excess because as a refugee he will be an add-on to the nation so long as his difference is what demands assimilation. Always only legible in conjunction with the nation-state, the refugee "breaks into the political scene as the alien" (Arendt [1951] 2003, p. 43). The refugee is a "surplus subject" (Ranciere 2004, p. 305).

With the emergence of stateless people, "mankind, for so long a time considered under the image of a family of nations, had reached the stage where whoever was thrown out of these tightly organized closed communities found himself thrown out of the family of nations altogether" (Arendt [1951] 2003, p. 34). Arendt's kinship metaphor emphasizes that so long as the nation-state is the measuring rod by which we capture humanity, we always posit similarity rather than difference as the point of reference. "The Russian refugees," Arendt pointed out, "were only the first to insist on their nationality and to defend themselves furiously against attempts to lump them together with other stateless people. Since then, not a single group of refugees or Displaced Persons has failed to develop a fierce, violent group consciousness and to clamor for rights as-and only as-Poles or Jews or Germans, etc." (Arendt [1951] 2003, p. 33). The refugees' "group consciousness" was the moral reflex of seeking a community inside which they could feel they belonged. Rather than allegiance to their country of origin, the refugees' remaking of a national community beyond the nation is similar to the fantasy of a missing limb, only marking the absence of a shared world. The refugee is stranded in a liminal space where she is not (yet) a future citizen of the country where she happens to be seeking refuge any more than she is (still) a citizen of the country she has left behind. It is indeed telling that the site of refuge is not a country, but a camp. "Bare life," as Agamben would put it, is life at the disposal of the state, life that can be taken without it registering as anything other than a mechanism for reinforcing the state.

The nation-state was a given for Arendt, as she did not believe in a world government (Benhabib 2004, p. 64). To view the refugee rather than the citizen as the "truth of humanity," as Arendt and Agamben urged us, require us to articulate an authentic cosmopolitan sensus communis that is not merely a synonym for generic humanity. This would have to be a sensus communis predicated on the concept of the rights to have rights" and on the contingency of rights (Balibar 2007, p. 729). Individuals do not own rights generically; rather, rights are qualities that individuals grant one another within a community (Balibar 2007, p. 732). Rights are protected and endorsed through the political feature of antinomy, or the right to difference. Antinomy facilitates autonomy by directly challenging an assimilative ethics, and focuses instead on the political value of community formed not only through the coming together of individuals around shared values and commitments, but formed through distinctions as well.

"To live together in the world," wrote Arendt in The Human Condition, "means essentially that a world of things is between those who have it in common, as a table is located between those who sit around it; the world, like every in-between, relates and separates men at the same time" (Arendt [1958] 1998, p. 52, my emphasis). This is a metaphor of conviviality, which recognizes, respects, and cultivates difference. Unlike imagining humanity through the metaphor of a family of nations, which uses kinship to suggest an inherent parceling into communities of similarity, the metaphor of conviviality reminds us to value the demands of difference that accompany others' points of view. The question then is: how to access another's standpoint against the pressures of an assimilative ethics disguised as cosmopolitan sensus communis-as in Zweig's case? This was an important question to Arendt. Kant, as she read him, had insisted that "when one judges and when one acts in political matters, one is supposed to take one's bearings from the idea, not the actuality, of being a world citizen and, therefore, also a Weltbetracher, a world spectator" (Arendt 1989, p. 76). Read alongside 
her reflections on statelessness and refuge, the notion of beholding the world from the perspective of the Weltbetrachter seems more normative than descriptive, and verges on (Zweig's) political anomie. The Weltbetrachter standpoint might have been a fit for Kant, the armchair traveler, but it was not a fit for Arendt the refugee. In what way, then, did Arendt endorse the notion of judging from the perspective of the world citizen?

The response might come from adjusting, along with Lisa Jane Disch, how we understand Arendt's notion of the basis of judgment, as realized rather than hypothesized intersubjectivity. In contrast to Kant, Arendt believed that judgment has to be shared with others and "cannot simply be imputed to them" (Disch 1994, p. 151). Sharing judgment requires just as much conveying one's own standpoint as it requires understanding the standpoints of others. Her rejection of empathy as a way of producing enlarged thinking along with her dismissal of compassion and pity-as I show shortly-stem from her insistence on the need to reveal and respect alterity through "predicative or argumentative speech, in which someone talks to somebody about something that is of interest to both because it inter-est, it is between them" (Arendt [1951] 2003, p. 266). This is how we create a bond with others rather than merely notice them from a distance, how we acknowledge their presence rather than merely their existence. An ethics of alterity, then, must become an ethics of communicability.

\section{The World Citizen and the Ethics of Communicability}

Melville and Dostoevsky presented Arendt, through the characters of Billy Budd and Jesus Christ of Nazareth in the Grand Inquisitor novella, ${ }^{8}$ with a dramatization of the difficulty of knowing another's standpoint without having access to his voice, and thus without being able to reconstruct his standpoint as a discursive universe. Billy suffers from a speech impediment; Jesus Christ is silent. Both are outside the realm of argument, and their moral purity either turns into evil or remains insignificant from a legal perspective.

The plot of Melville's novella, which has inspired many scholarly debates, ${ }^{9}$ is well known. Billy is a young and handsome man serving aboard the Bellipotent in 1797, when the royal navy is recovering from a series of mutinies and facing the threat of the French Revolution. Billy is liked by everyone except the master-at-arms, Claggart, who tries to frame him for a crime Billy never committed. Outraged by the accusation, Billy loses his temper and kills Claggart. The ship's captain, Vere, sentences Billy to death in accordance with legislation imposed by the Mutiny Act, which sanctions severely any act of violent disturbance in the royal navy. Billy does not protest the sentence and dies crying out "God bless Captain Vere!" In Dostoevsky's novella, Jesus Christ returns to earth in Seville at the time of the Inquisition and starts performing miracles in the adoration of the people. He is arrested as a heretic and sentenced to death, but the Grand Inquisitor visits Jesus at night in his cell and offers him freedom if Christ agrees to leave and never return again. Christ listens and departs quietly.

While Arendt does not explicitly read in the protagonist of Melville's Billy Budd, Sailor the figure of the refugee, she notes that Billy is a foundling. He has no known origin. Billy's angelic beauty and innocent mind are descriptors of a humanity both idealized and laid bare. Billy joins Captain Vere's ship Bellipotent after serving on the Rights of Man. The conspicuous symbolism of names aside, the ships serve as metonyms of statehood, as well as of the camp. Billy has no say in leaving one ship for the other, and once on the Bellipotent, he cannot go anywhere else. Similar to the refugee, Billy lacks not only "the right to freedom, but ... the right to action; not ... the right to think whatever (he) please(s), but ... the right to opinion (Arendt [1951] 2003, p. 39). He accepts his sentence. Billy's last words-“God bless Captain Vere!"- not only present him as acquiescing, but also render his standpoint opaque: we do not know if he is resigned or remorseful.

8 I will mostly focus here on Arendt's reading of Melville's novella, to which she herself devotes more attention than to the Brothers Karamazov excerpt.

9 For detailed reviews of the scholarship dedicated to interpreting the political allegory of Billy Budd, Sailor see (Schiffman 1950; Rosenberry 1965; Ramirez and Ronner 2004; Solove 2005). 
Melville presents Billy's recourse to violence as a consequence of his inability to articulate discourse. He stutters in emotionally charged moments, when he is angry or fearful. Violent emotions breed violent actions, whereas judgment can create agreement and establish peace-as Vere does. Richard Bernstein has pointed out that Arendt's vision of the political excludes violence, because it deems it too bluntly instrumental (Bernstein 2011). Billy is powerless because he has no speech when he would most need it. His standpoint is incommunicable or a-rhetorical, reducible to mute anger or absolute candor.

Political judgment, as Arendt understood it, has a requirement of communicability and intelligibility. Claggart's death demands from Vere, as captain of the ship, a judgment that starts with making sense of the event publicly. From a moral perspective, the crime can be seen as righteous revenge against an evil man, but from Vere's political standpoint it is inscribed in the larger logic of mutiny. Vere's political judgment establishes the structures of intelligibility in which characters and actions are embedded. ${ }^{10}$ As captain of the ship, Vere represents the sovereign state, and as such he can only see Claggart's death as challenging the legitimacy of the only authority that can claim to use violence legitimately: the state itself. ${ }^{11}$ While Arendt does not mention this aspect, it is worth noting that after the execution, Billy is identified in a newspaper article as a foreign influence on the ship, trying to incite to the violence of revolution. Billy's ultimate culpability is his alienness.

Melville offered Arendt an allegory of political judgment that must be exercised in a situation in which an absolute good is "hardly any less dangerous than absolute evil" (Arendt [1951] 2003, p. 262). Billy represents an angelic figure of utmost beauty and kindness, yet he strikes a man to death. In her reading, "Melville reversed the primordial legendary crime, Cain and Abel to take away the consolation that violence is the characteristic of evil" (Arendt [1951] 2003, p. 266). Without a clear demarcation of good and evil, compassion loses ethical ground: can the reader, or indeed Vere, feel compassion toward Billy, as he meets his death punishment for having killed another man, and still recognize that killing is an evil act? The moral contrast upon which Melville's novella is built is not only a contrast between Billy and Claggart, but between Billy and his own violent act as well, and is designed to show that "the absolute ... spells doom to everyone when it is introduced into the political realm" (Arendt [1951] 2003, p. 264). What we are missing is a relational ethics focused on opening up one's standpoint, before we can presume to access it.

Much of the work produced under the auspices of the ethical turn would point to empathy as compassion as the access to another's standpoint. Arendt would disagree. She dismissed the role of compassion in re-creating another's standpoint because she followed the Aristotelian treatment of pity and compassion. We feel pity, Aristotle maintained, for those who are "like us but, not us and in situations that are proximal, yet not imminent." This assumption of similarity between the sufferer and the witness is in counter-distinction to Arendt's emphasis on difference as a feature of the political. Pity and compassion, as envisioned by Aristotle, do not entail alterity. On the contrary, their rhetorical mechanism is one of similarity: we feel pity for the misfortune of others insofar as we can imagine the same fate might befall us. The Rhetoric takes a dramatic approach to the production of pity and recommends that suffering be put clearly on display and acted out (Aristotle 1984).

To Arendt, such theatricality could only have been suspect of kitsch from an aesthetic perspective, as well as of moral shallowness and political ineffectiveness. Theatricality puts suffering on display and thus keeps the sufferer at a distance precisely as pitiable, in a way that discourages any attempt at action. ${ }^{12}$ Billy's simple-mindedness, his stutter, and his seeming history of trauma make him not

10 The faculty of judgment, as Beiner argues, is "in the service of human intelligibility" (Beiner 1989, p. 100).

11 Vere sacrifices his private morality—according to which Billy was justified in striking Claggart—in order to enact a public justice based on a political principle. Arendt's reading of Melville's novella is consistent with her view of political action, which, as Donald Klusmeyer observes, "required individuals to put a commitment to the public good before their personal interest in preserving their own moral purity" (Klusmeyer 2009, p. 345).

12 Arendt's was critical of a political culture emerging from societies in which theatre played an important role, because these societies were under the spell of fame and stardom. "A culture built around an actor or virtuouso," she writes about 
only piteous but pitiful as well. As pity risks sliding into condescension, an ethics driven primarily by empathy and compassion not only fails to articulate an enlarged thinking, but risks sliding into mere display of self-righteousness and moral (or intellectual) arrogance as well.

Aaron Ben-Ze'ev concept of sympathetic sorrow captures what happens when feeling sorry for another allows us to consume a tragic story precisely as a story: we believe ourselves to be "unable to offer ... real help," and pay attention only to the suffering itself rather than thinking of ways to end it. "The perceived impotence and lack of obligation in pity," Ben Ze'ev writes, "is not necessarily real. In many cases we could help but perceive ourselves as being unable, or not obliged, to do so because of certain perceived constraints (Ben Ze'ev 2000, p. 6). Sympathetic sorrow can function as a moral alibi for inaction.

An ideal polity, if we follow Arendt's thinking, develops ethical ties that avoid at once the hollowness of sympathetic sorrow, the condescension of pity, and the ineffectiveness of compassion. The vision of such a polis appears in her commentary of a little-known story by Adalbert Stifter, "Rock Crystals," translated into English by Marianne Moore-significantly by a poet particularly attuned to Stifter's semantic nuance. The story features two children who get lost in the snow as they return home from their grandparents' house in the neighboring village. The kids, brother and sister, travel regularly across a mountain between two villages as the only emissaries connecting feuding people. They are progenies of parents who had defied the interdiction and had married someone from the enemy group. Because they are unaware of the danger, the children are never afraid of the mountain or the ice and remain fully trusting that they will find the way home, unlike the adults who meanwhile are searching for them anxiously, gradually losing hope. The children experience their night in the ice storm aesthetically, awed by the beauty of the nature surrounding them, described in precise detail by Stifter. The emotional tension of the text derives from the contrast between the children's confidence and the reader's awareness of the threat, which creates the adumbration of a tragic ending. We logically anticipate that the children will freeze to death. Stifter's mastery lies in shifting the narrative focus entirely onto the children against the backdrop of the rich description of a sublime and merciful nature. We can see the world through the children's eyes, and it is only from their morally pure perspective that we can see beauty rather danger.

Beautiful and benevolent, the icy world in which the children are lost is a powerful political utopia. The children's innocence, Arendt comments, "fits so well in the sublime majesty of the mountain that they can patiently wait until the village comes to their rescue" (Arendt 2007b, p. 113). Unlike Billy the orphan, the children are defined by their belonging - to a family and to a community. The happy ending of the story, a reunification, becomes an opportunity for reconciliation for the adults. They enter a bond of solidarity in the name of shared love for their children, transcending any difference that had separated them into residents of two villages. To frame it in Rilkean terms: the children rescue the adults from their estrangement.

The topoi of absolute freedom featured in Stifter's story, nature and childhood, are in marked counter-distinction to the topos of nation-state. These topoi create a utopia of a sublime and peaceful world in which harm is not possible. The children illustrate Arendt's concept of natality, the capacity of human beings to bring new human beings into the world, and with them, to begin anew. While for Agamben birth bears the ominous ascription of citizenship, Arendt's notion of natality is defined by hope. If the state claims us as individuals already at birth and identifies us as either citizens or aliens, engaging with another's standpoint through aesthetic representations gives us a chance to begin anew, to "read ... (stories and poems) as though nobody had ever read them before" (Arendt 1961, p. 204). We can read Stifter's representation of a sublime frozen forest as a metaphor for cultural traditions that can be continuously renewed as objects of beauty rather than as inherited, forbidding, norms.

Viennese society and its fascination with theatre, "established standards that were as novel as they were dubious" (Arendt [1948] 2007a, p. 64). 
This metaphor can be a reminder that the task of our cultural ethics is not to maintain or restore tradition, but rather, as Dana Villa points out, "to deconstruct and overcome the reifications of a dead tradition" (Villa 1996, pp. 8-9), so that, we might add, we can continuously rediscover its beauty. Such a view can let us imagine a cosmopolitan sensus communis in which our judgments are always provisional, embedded in ongoing acts of persuasion that are never complete, or limited to expressing a given set of beliefs, customs, or even norms. Configured in Arendt's terms, ethically defensible judgment emerges across different viewpoints that can be connected and rendered mutually intelligible in the tissue of sensus communis, ready to withstand the pressures of conformity and assimilation. What it takes to achieve this goal is the courage of self-disclosure as an act of individual affirmation-even at the risk of self-annihilation - as well as a commitment to entering another's world looking for its structures of intelligibility as the lines and shapes of a reality blueprint we can all share.

\section{Conclusions}

Arendt's literary ethics was keenly attuned to fulfilling the promise of a cosmopolitan sensus communis, without letting it use the pretext of a general humanity to obtain assimilation and thus to contain alterity. She pursued, through her reflections on literary practice, a political need to transcend "individual limitations by seeing "things not only from one's own point of view but in the perspective of all those who happen to be present" (Arendt 1961, p. 221). For Arendt, literature's task is to immerse us into our present and sharpen our understanding of our reality, rather than release us from it. If she was so critical of Zweig's suicidal despair, "turning on him with surging venom" (Steinberg 2007, p. 879), it is not because she was detached from the tragedy of Jews, but because she believed she understood the standpoint of the Jewish refugee too well, and from that standpoint the action she saw necessary was one of political resistance instead of capitulation. Contemplating others' actions and judgments from a distance-or seeking to come close to them through empathy and compassion but without trying to understand the viewpoint from which they originate-makes no real ethical demands on us. If we regard another's perspective as part of our achieving a self-righteous catharsis, or feeling satisfied with our ability to feel sorry for others without any responsibility for alleviating their suffering, our response to it is unethical as well as a failure to open up to the cognitive and affective demands of representation.

Our ethical and moral decisions are informed by the aesthetic representations that nourish our imagination and establish the "company we keep" (Beiner 1989, p. 113). Arendt's company included poets such as W. H. Auden and W. B. Yates, whom she admired because they were "hurt into poetry" (Arendt [1975] 2007). She, too, was "hurt" into seeking in literature structures of intelligibility that could shed light into the tragic events humanity experienced throughout her lifetime. In the eulogy he delivered at Arendt's death in 1976, Hans Jonas summed up her philosophy of life: "persecution aroused her ... moral indignation armed her, extreme distress called her into the active life" (Jonas 1976, p. 3).

Our ethical practices might require at times resistant readings through which we can distance ourselves from the beliefs and attitudes represented in a text. However, in so doing, we can devalue others' values and behaviors and re-affirm the primacy of our own. Ethical difference, then, is recognized but at the same time suppressed through our acts of evaluating moral choices. By contrast, to engage in "ethics while reading" is to turn our attention "to moral issues generated by events described within an imagined world" (Schwartz 2001, p. 12) and to challenge ourselves to imagine what kind of a response makes sense from the standpoint of those who are in it, even if, or especially when such a standpoint is alien to us. "Messenger of ill tidings," to use Brecht's metaphor (Arendt [1948] 2007a, p. 237), the refugee is a figure of alterity that can remind us of how our cultural traditions perpetuate values that continuously inform an aesthetic-political judgment hostile to difference, no matter how much we declare our ethical allegiance to the other.

Funding: This research received no external funding.

Conflicts of Interest: The authors declare no conflict of interest. 


\section{References}

Agamben, Giorgio. 1995. We Refugees. Symposium: A Quarterly Journal of Modern Literatures 49: 114-19. [CrossRef] Arendt, Hannah. 2007. Rilke's Duino Elegies (with Günther Stern). In Reflections on Literature and Culture. Stanford: Stanford University Press, pp. 1-23. First published in 1930.

Arendt, Hannah. 2007. Stefan Zweig: Jews in the World of Yesterday. In Reflections on Literature and Culture. Stanford: Stanford University Press, pp. 58-68. First published in 1943.

Arendt, Hannah. 2008. We Refugees. In The Jewish Writings. Edited by Jerome Kohn and Ron H. Feldman. New York: Schocken Books. First published in 1943.

Arendt, Hannah. 2007a. Beyond Personal Frustration: The Poetry of Bertolt Brecht. In Reflections on Literature and Culture. Stanford: Stanford University Press, pp. 133-42. First published in 1948.

Arendt, Hannah. 2007b. Franz Kafka, Appreciated Anew. In Reflections on Literature and Culture. Stanford: Stanford University Press, pp. 94-109. First published in 1948.

Arendt, Hannah. 2003. The Perplexities of the Rights of Man. In The Portable Hannah Arendt. Edited and with an introduction by Peter Baehr. New York: Penguin Books, pp. 31-45. First published in 1951.

Arendt, Hannah. 1998. The Human Condition, 2nd ed. Introduction by Margaret Canovan. Chicago: The University of Chicago Press. First published in 1958.

Arendt, Hanna. 1961. The Crisis in Culture: Its Social and Political Consequences. In Between Past and Future. Six Exercises in Political Thought. New York: Viking Press.

Arendt, Hannah. 2003. The Social Question. In The Portable Hannah Arendt. London: Penguin Classics, pp. 247-77. First published in 1963.

Arendt, Hannah. 2000. What Remains? The Language Remains: A Conversation with Gunter Gauss. In The Portable Hannah Arendt. New York: Penguin Books. First published in 1964.

Arendt, Hannah. 1968. Introduction. Walter Benjamin: 1892-1940. In Benjamin, Walter. Illuminations. Edited by Hannah Arendt. Translated by Harry Zohn. New York: Schocken Books.

Arendt, Hannah. 2007. Remembering Wystan H. Auden, Who Died in the Night of the Twenty-eight of September, 1973. In Reflections on Literature and Culture. Stanford: Stanford University Press, pp. 294-302. First published in 1975.

Arendt, Hannah. 1989. Lectures on Kant's Political Philosophy. Chicago: The University of Chicago Press.

Arendt, Hannah. 2007a. Great Friend of Reality: Adalbert Stifter. In Reflections on Literature and Culture. Stanford: Stanford University Press, pp. 110-14.

Arendt, Hannah. 2007b. Reflections on Literature and Culture. Edited and with an introduction by Susannah Young-ah Gottlieb. Stanford: Stanford University Press.

Aristotle, Rhetoric. 1984. The Complete Works of Aristotle. Edited by Jonathan Barnes. Princeton: Princeton University Press.

Attridge, Derek. 2004. The Singularity of Literature. Abingdon: Routledge.

Balibar, Etienne. 2007. (De)Constructing the Human as Human Institution: A Reflection on the Coherence of Hannah Arendt's Practical Philosophy. Social Research 3: 727-38.

Barber, Benjamin. 2010. Hannah Arendt between Europe and America. In Politics in Hard Times: Encounters with Hannah Arendt. Cambridge: Cambridge University Press.

Beiner, Ronald. 1989. Interpretive Essay. In Lectures on Kant's Political Philosophy. Chicago: The University of Chicago Press.

Ben Ze'ev, Aaron. 2000. The Subtlety of Emotions. Cambridge: MIT Press.

Benhabib, Seyla. 2004. The Rights of Others. Aliens, Residents, and Citizens. Cambridge: Cambridge University Press.

Benhabib, Seyla. 1988. Judgment and the Moral Foundations of Politics in Arendt's Thought. Political Theory 16: 29-51. [CrossRef]

Bernstein, Richard. 2011. Hannah Arendt's Reflections on Violence and Power. Iris 3: 3-30.

Boym, Svetlana. 2012. Another Freedom. The Alternative Vision of an Idea. Chicago: The University of Chicago Press.

Brooks, Peter. 2014. Introduction. In The Humanities and Public Life. Edited by Peter Brooks and Hilary Jewett. New York: Fordham University Press, pp. 1-14.

Butler, Judith. 2011. Who Owns Kakfa. London Review of Books, March 3.

Davis, Todd F., and Kenneth Womack. 2001. Mapping the Ethical Turn. A Reader in Ethics, Culture, and Literary Theory. Charlottesville: University of Virginia Press. 
Disch, Lisa Jane. 1994. Hannah Arendt and the Limits of Philosophy. Ithaca: Cornell University Press.

Eskin, Michael. 2004. On Literature and Ethics. Poetics Today 25: 573-94. [CrossRef]

Gottlieb, Susannah Young-ah. 2007. Introduction. In Reflections on Literature and Culture. Stanford: Stanford University Press, pp. xi-xxi.

Harpham, Geoffrey Galt. 1995. Ethics. In Critical Terms for Literary Study. Edited by Frank Lenttrichia and Thomas McLaughlin. Chicago: The University of Chicago Press.

Heller, Erich. 1977. Hannah Arendt as a Critic of Literature. Social Research 44: 147-59.

Jonas, Hans. 1976. Hannah Arendt. Social Research 43: 3-5.

King, Richard. 2017. Hannah Arendt and the Uses of Literature. Raritan A Quarterly Review 36: 4.

Klusmeyer, Douglas. 2009. Beyond Tragedy: Hannah Arendt and Hans Morgenthau on Responsibility, Evil and Political Ethics. International Studies Review 11: 332-51. [CrossRef]

Lang, Berel. 2010. The Ethics of Style in Philosophical Discourse. In Literary Form, Philosophical Content. Historical Studies on Philosophical Genres. Edited by Jonathan Lavey and Louis Groarke. Madison: Farleigh Dickinson University Press.

Lupton, Julia Reinhardt. 2014. Hannah Arendt and the Crisis of the Humanities? Political Theology 15: $287-89$. [CrossRef]

Meretoja, Hanna. 2017. The Ethics of Storytelling. Narrative Hermeneutics, History, and the Possible. Oxford: Oxford University Press.

Nguyen, Mimi Thi. 2012. The Gift of Freedom. War, Debt, and Other Refugee Passages. Durham: Duke University Press.

Nisbett, Robert. 1977. Hannah Arendt and the American Revolution. Social Research 44: 63-79.

Norris, Andrew. 1996. Arendt, Kant, and the Politics of Common Sense. Polity 29: 165-91. [CrossRef]

Nussbaum, Martha Craven. 1992. Love's Knowledge: Essays on Philosophy and Literature. Oxford: Oxford University Press.

Pettman, Dominic. 2017. Sonic Intimacy. Voice, Species, Technics (Or, How to Listen to the World). Stanford: Stanford University Press.

Ramirez, Juan, Jr., and Amy D. Ronner. 2004. Voiceless Billy Budd: Melville's Tribute to the Sixth Amendment. CWSL Scholarly Commons. Available online: http://scholarlycommons.law.cwsl.edu/cwlr/vol41/iss1/3 (accessed on 27 August 2019).

Ranciere, Jacques. 2004. Who is the Subject of the Rights of Man? The South Atlantic Quarterly 103: 298-310. [CrossRef]

Ritivoi, Andreea Deciu. 2014. Intimate Strangers: Arendt, Marcuse, Solzhenitsyn, and Said in American Political Discourse. New York: Columbia University Press.

Rorty, Richard. 1989. Contingency, Irony, and Solidarity. Cambridge: Cambridge University Press.

Rosenberry, Edward H. 1965. The Problem of Billy Budd. PMLA 80: 489-98. [CrossRef]

Sacks, Rabbi. 2016. The Spirituality of Listening. Available online: http://rabbisacks.org/spirituality-listeningekev-5776/ (accessed on 16 September 2019).

Schiffman, Joseph. 1950. Melville's Final State, Irony: A Re-Examination of Billy Budd Criticism. American Literature 22: 128-36. [CrossRef]

Schwartz, Jonathan P. 2015. To Choose One's Own Company: Arendt, Kant, and the Political Sixth Sense. European Journal of Political Theory 18: 108-27. [CrossRef]

Schwartz, Daniel. 2001. A Humanistic Ethics of Reading. In Mapping the Ethical Turn. Charlottesville: University of Virginia Press, pp. 3-15.

Singer, Alan. 1997. Aesthetic Community: Recognition as an Other Sense of Sensus Communis. Boundary 2 24: 205-36. [CrossRef]

Sjöholm, Cecilia. 2015. Doing Aesthetics with Arendt: How to See Things. New York: Columbia University Press.

Solove, Daniel J. 2005. Melville's Billy Budd and Security in Times of Crisis. Cardozo Law Review 26: $2443-70$.

Steinberg, Michael. 2007. Hannah Arendt and the Cultural Style of German Jews. Social Research 74: 879-902.

Stonebridge, Lyndsey. 2011. Refugee Style: Hannah Arendt and the Perplexities of Rights. Textual Practice 25: 71-85. [CrossRef]

Storey, Ian. 2015. The Reckless Unsaid: Arendt on Political Poetics. Critical Inquiry 41: 869-92. [CrossRef]

Villa, Dana. 1996. Arendt and Heidegger. The Fate of the Political. Princeton: Princeton University Press.

Scarry, Elaine. 2014. Poetry, Injury, and the Ethics of Reading. In The Humanities and Public Life. New York: Fordham University Press, pp. 41-48. 
Weigel, Sigrid. 2012. Sounding Through-Poetic Difference-Self-Translation. In Hannah Arendt's Thoughts and Writings Between Different Languages, Cultures, and Fields. Edited by Eckart Goebel and Sigrid Weigel. Berlin: De Gruyter, pp. 55-79.

() (1)

(C) 2019 by the author. Licensee MDPI, Basel, Switzerland. This article is an open access article distributed under the terms and conditions of the Creative Commons Attribution (CC BY) license (http://creativecommons.org/licenses/by/4.0/). 